\title{
Pregnancies and improved early embryonic development with bovine oocytes matured in vitro with 9-cis-retinoic acid
}

\author{
C. O. Hidalgo, C. Díez, P. Duque, N. Facal and E. Gómez* \\ SERIDA-CENSYRA, Camino de los Claveles, 604 Somió, 33203 Gijón, Spain
}

\begin{abstract}
Retinoids have an important role in cell growth, morphogenesis and differentiation. In the present study the developmental potential of bovine oocytes was examined after in vitro maturation in the presence of 9-cis-retinoic acid, a vitamin A metabolite, at $5 \mathrm{nmol} \mathrm{I}^{-1}$ in chemically defined conditions. Experiments studied early in vitro development, blastocyst differential cell counts and the capacity of embryos to establish pregnancy after transfer to recipients. After in vitro fertilization and culture in simple medium, blastocyst development and hatching rates increased in oocytes matured with 9-cis-retinoic acid. Addition of ethanol (used as a solvent for 9-cis-retinoic acid) resulted in higher cell counts and proportions of cells in the inner mass of day 7 blastocysts. Day 8 blastocysts represented most differences observed in the number of
\end{abstract}

cells. In these embryos, ethanol and 9-cis-retinoic acid increased both the number of cells and proportions in the inner mass. However, while ethanol treatment reduced the number of cells in the trophectoderm, 9-cis-retinoic acid did not. The total number of cells was unaffected by treatment within 1 day, although untreated oocytes lead to day 8 blastocysts with reduced total cell counts. Once transferred to recipients, both fresh and vitrifiedwarmed blastocysts derived from oocytes matured with 9-cis-retinoic acid yielded more pregnancies at day 60. Modifications of retinoid metabolism affect development and trophectoderm differentiation, and in vitro maturation with 9-cis-retinoic acid increased the developmental competence of the oocyte.

\section{Introduction}

Vitamin A (all-trans-retinol) and its metabolites are regulators of cellular growth, embryonic morphogenesis and differentiation in many types of cell. These compounds, members of the retinoid family, play a fundamental role in controlling events during the cell cycle, affecting decisions to continue proliferation or to differentiate along a specific pathway. The all-trans-retinol metabolite retinoic acid is the most important retinoid for vertebrate embryogenesis (Morriss-Kay and Ward, 1999), although maintenance of pregnancy in mammals is strongly dependent on all-trans-retinol. In vivo, all-transretinoic acid binds to retinoic acid receptors (RARs; $\alpha, \beta$ and $\gamma$ ), and 9-cis-retinoic acid binds specifically to retinoid X receptors (RXRs; $\alpha, \beta$ and $\gamma$ ) (Mangelsdorf et al., 1994; Chambon, 1996); all-trans-retinoic acid is converted to 9-cis-retinoic acid and other isomers in a reversible way. However, isomerization does not occur in vitro and 9-cis-retinoic acid activates both RXRs and RARs. When activated, the RAR-RXR nuclear receptors heterodimerize and are capable of binding to specific DNA sequences named retinoic acid response elements (RAREs), to increase or decrease the expression of a gene.

*Correspondence

Email: egomez@serida.org
In addition, the RXRs may form homodimers and other heterodimers with thyroid hormone receptor, vitamin D receptor and peroxisome proliferator-activated receptor (Chambon, 1996), which may explain the pleiotrophic effects of retinoids. Information of RXRs and 9-cisretinoic acid, the so-called second retinoid signalling pathway, is scarce and focused on later embryonic stages in mice (Mangelsdorf et al., 1992; Dolle et al., 1994).

Recently, subtypes RAR $\alpha, R A R \gamma, R X R \alpha, R X R \beta$ and retinaldehyde dehydrogenase- $2(\mathrm{RALDH} 2)$ have been detected in bovine embryos developed in vitro, from the oocyte to the hatched blastocyst stage (Mohan et al., 2001, 2002). Immunostaining revealed the presence of proteins for RAR $\alpha$ and RAR $\beta$ (Mohan et al., 2001) and RXRß (Mohan et al., 2002) in the trophectoderm and in the inner cell mass (ICM) from zona pellucida included and hatched blastocysts. Accordingly, evidence was given that the developmental capacity of the oocytes can be stimulated by retinoids. Thus, alltrans-retinol administration to donor animals improved embryonic quality in both superovulated cows (Shaw et al., 1995) and sheep (Eberhardt et al., 1999), and in non-superovulated gilts (Whaley et al., 1997, 2000). In addition, more oocytes and embryos were obtained in response to superovulation from rabbits that had higher blood concentrations of vitamin A (Besenfelder et al., 1996). Increased all-trans-retinol concentrations 
are characteristic of healthy, in contrast to atretic, follicles in sheep (Eberhardt et al., 1999). In our laboratory donor cows injected with all-trans-retinol yield more oocytes (Hidalgo et al., 2002), and oocytes pre-matured with 9-cis retinoic acid show increased development, cryopreservation tolerance and quality of blastocysts (Duque et al., 2002). The effects of all-trans-retinol are regulated by specific linkage to retinol-binding proteins (RBP). These chaperone elements are found in bovine oocytes (Mohan et al., 2001), whereas the cellular RBP (CRBP) is detected in rat oocytes, nearby granulosa cells (Wardlaw et al., 1997) and in human ovaries (Ong and Page, 1986). At the cell, all-trans-retinol is metabolized to retinoic acid, which binds to cellular retinoic acidbinding proteins (CRABP). All-trans-retinol accumulates in the cell forming more stable retinyl esters, with palmitate the usual combination for storage. Palmitate is the most abundant fatty acid in bovine (McEvoy et al., 2000; Kim et al., 2001), porcine and ovine (McEvoy et al., 2000) oocytes. This evidence suggests that endogenous retinoid could have an effect on oocyte development and should be taken into account in experiments in which exogenous compounds are incorporated.

A site-restricted synthesis of retinoic acid from all-trans-retinol has been described (Morriss-Kay and Ward, 1999), but little is known about which cells produce retinoic acid and under what circumstances. Rat granulosa cells synthesize retinoic acid from all-transretinol (Zheng et al., 1999), and the presence of RARs demonstrates that these cells are targets for retinoic acid in rats, humans and mice (Zhuang et al., 1994). Retinoids could act to modify the transcriptional activity within the cumulus-oocyte complex (COC), exerting their effects directly on the oocyte, the adjacent cumulus-granulosa cells or both. As a consequence, in vitro maturation (IVM) and subsequent development might be influenced by retinoids. In the present study the effects of 9-cisretinoic acid added during the bovine IVM on embryonic development were investigated, together with quality of blastocyst produced, measured as differential cell counts, and the ability to establish pregnancies once transferred into recipients.

\section{Materials and Methods}

All chemicals were purchased from Sigma (Madrid), unless otherwise indicated.

\section{Oocyte recovery}

Oocytes for in vitro experiments were obtained from bovine ovaries at an abattoir, whereas blastocysts transferred to recipients were obtained from healthy cows by ovum pick-up. Ovaries from Asturiana de los Valles cows were placed in $\mathrm{NaCl}\left(9 \mathrm{mg} \mathrm{ml}^{-1}\right)$ containing antibiotics (100 iu penicillin $\mathrm{ml}^{-1}$ and $100 \mu \mathrm{g}$ strepto- mycin sulphate $\mathrm{ml}^{-1}$ ) and maintained at $30-35^{\circ} \mathrm{C}$ until recovery of COCs. Ovaries were washed twice in distilled water and once in freshly prepared saline. COCs were aspirated from $2-7 \mathrm{~mm}$ visible follicles through an 18-gauge needle connected to a syringe and recovered into a $50 \mathrm{ml}$ Corning tube. Follicular fluid and COCs were placed in an ovum concentrator (Em-Con, Comextrade, Tarragona) and rinsed three times with holding medium consisting of TCM199 (Invitrogen, Barcelona), $25 \mathrm{mmol}$ Hepes $\mathrm{I}^{-1}$ and $0.4 \mathrm{~g} \mathrm{BSA} \mathrm{I}^{-1}$, supplemented with 2 iu heparin $\mathrm{ml}^{-1}$.

\section{In vitro maturation}

Only oocytes enclosed in a compact cumulus with evenly granulated cytoplasm were selected for maturation. The COCs were washed three times in holding medium and twice in maturation medium, which consisted of bicarbonate-buffered TCM199, $1 \mu \mathrm{g}$ FSHp ml $-1,5 \mu \mathrm{g} \mathrm{LH} \mathrm{ml}{ }^{-1}, 1 \mu \mathrm{g}$ oestradiol $\mathrm{ml}^{-1}$ and $0.5 \mathrm{mg}$ polyvinyl alcohol $\mathrm{ml}^{-1}$. 9-cis-Retinoic acid was dissolved in ethanol, divided into aliquots and stored at $-80^{\circ} \mathrm{C}$ in the dark. Treatments within maturation were: (1) $5 \mathrm{nmol} 9$-cis-retinoic acid $\mathrm{I}^{-1}$; (2) $1 \%$ ethanol (vehicle); (3) no additives (negative control); and (4) 10\% fetal calf serum (FCS; positive control). Maturation was performed by culturing approximately 50 COCs in $500 \mu \mathrm{l}$ of maturation medium in four-well dishes at $39^{\circ} \mathrm{C}$ in $5 \% \mathrm{CO}_{2}$ in air and high humidity for 22 to $24 \mathrm{~h}$.

\section{In vitro fertilization}

Sperm separation was carried out using a swimup procedure similar to that reported by Parrish et al. (1986). Briefly, semen from one frozen straw of a single bull was thawed in a water bath and added to a polystyrene tube containing $1 \mathrm{ml}$ of pre-equilibrated Sperm-Tyrode's albumin lactate pyruvate (TALP). After $1 \mathrm{~h}$ of incubation, approximately $700 \mu \mathrm{l}$ of the upper layer of supernatant containing the motile spermatozoa was removed. The spermatozoa were then centrifuged for $7 \mathrm{~min}$ at $200 \mathrm{~g}$ and the supernatant was aspirated to leave a pellet of approximately $100 \mu \mathrm{l}$. Spermatozoa concentration was determined with a haemocytometer. The COCs were washed twice in holding medium and placed in four-well culture dishes containing preequilibrated fertilization medium (Fert-TALP) with $10 \mu \mathrm{g}$ heparin $\mathrm{ml}^{-1}$ (Calbiochem, La Jolla, CA). Spermatozoa were then added at $2 \times 10^{6}$ cells ml $^{-1}$ in $500 \mu \mathrm{l}$ of medium per well containing $\leqslant 100$ COCs. IVF was accomplished by incubating oocytes and sperm cells together for $18-20 \mathrm{~h}$ at $39^{\circ} \mathrm{C}$ in $5 \% \mathrm{CO}_{2}$ and high humidity. As a control for oocyte activation induced by ethanol, some COCs matured in $1 \%$ ethanol and negative control were cultured in Fert-TALP with heparin but without spermatozoa. 
In vitro culture

Presumptive zygotes were vortexed for $2 \mathrm{~min}$ to separate cumulus cells and washed three times in holding medium and once in synthetic oviduct fluid (SOF) before being transferred to droplets. Embryo culture was performed in SOF containing amino acids, citrate and myo-inositol (Holm et al., 1999) (285 mOsm, $\mathrm{pH}$ 7.2-7.3), to which 5\% FCS was added at $66 \mathrm{~h}$ after fertilization. Droplets of culture medium (1-2 $\mu$ l per embryo) were prepared under mineral oil in four-well dishes and equilibrated in an incubator for $2 \mathrm{~h}$ before addition of zygotes. Culture was carried out at $39^{\circ} \mathrm{C}, 5 \%$ $\mathrm{CO}_{2}, 5 \% \mathrm{O}_{2}$ and $90 \% \mathrm{~N}_{2}$. Culture media were renewed at $66 \mathrm{~h}$ (day 3 ) and $138 \mathrm{~h}$ (day 6) after fertilization, and embryonic development was evaluated on days 3, 6, 7 and 8 .

\section{Differential cell counting in blastocysts}

Cells were counted in fully expanded and hatched blastocysts at day 7 and day 8 in each experimental group. These embryos were selected, fixed and stained for differential cell counts as described by Van Soom et al. (1996). Briefly, expanded embryos were incubated in PBS $+5 \%$ pronase for $1 \mathrm{~min}$ and in acid Tyrode's solution for $1 \mathrm{~min}$ to remove the zona pellucida. Subsequently, expanded and hatched blastocysts were incubated in trinitrobenzenesulphonic acid and rabbit antiserum (antiDNP-BSA) solution. Thereafter, the blastocysts were incubated in guinea-pig complement serum for $30 \mathrm{~min}$ at $39^{\circ} \mathrm{C}$ and subsequently washed in TCM199 Hepes $+10 \mu \mathrm{g}$ propidium iodide $\mathrm{ml}^{-1}$. Samples were fixed in ethanol and incubated in bisbenzimide (Hoechst 33342 in $10 \mu \mathrm{l}$ ethanol $\mathrm{ml}^{-1}$ ). Finally, after mounting on a glass slide the samples were evaluated under a fluorescence microscope at $\times 400$ with an excitation filter of 330-385 nm and barrier filter of $420 \mathrm{~nm}$. Cells from the trophectoderm fluoresce red whereas the ICM appears blue.

\section{Embryo transfer}

Blastocysts at day 7 from the groups of COCs matured with 9-cis-retinoic acid and no additives (negative control) were selected for embryo transfer. Embryos transferred fresh were blastocysts and expanded blastocysts, while embryos transferred after vitrification and warming were expanded blastocysts. For vitrification, embryos were loaded into straws in PBS (Invitrogen, Barcelona) with glycerol, ethylene glycol and FCS, adjacent to two fractions of galactose solution (Kaidi et al., 2000). Embryos were warmed for $5 \mathrm{~s}$ in air and $10 \mathrm{~s}$ in a water bath at $30^{\circ} \mathrm{C}$. The content of the straws was transferred to a Petri dish and embryos were mixed in the galactose solution by slight agitation. After 5 min, embryos were transferred to PBS + 20\% FCS for 5 min. Embryos were allowed to re-expand in B2 INRA Ménézo (C.C.D., Paris) at $39^{\circ} \mathrm{C}$ in an incubator. Finally, re-expanded embryos were loaded into $0.25 \mathrm{ml}$ straws and non-surgically transferred into synchronized Asturiana de los Valles heifers, aged 15-18 months. Each animal received either one fresh embryo or two vitrified embryos in the uterine horn adjacent to a corpus luteum. Pregnancy diagnosis was established by analysing plasma progesterone concentration (> $2.5 \mathrm{ng} \mathrm{ml}^{-1}$ ) on day 21 and ultrasonography on day 35 and subsequent confirmation at day 60 .

\section{Statistical analyses}

Data from embryo development and blastocyst differential cell counts were analysed in two steps. First, since these values can be represented by contingency tables, those factors significantly affecting the variables were identified by means of the procedure Categorical Data Modelling (CATMOD; SAS Version 8.2, 1999; SAS Institute Inc., Cary, NC). CATMOD extends analysis from continuous data to categorical data, fitting linear models to functions of response frequencies. Treatment and replicate were found to have significant influence on dependent variables. Second, factors identified as significant were used to fit a linear model using the General Linear Models (GLM; SAS) procedure. This procedure performs analysis of variance for unbalanced data. GLM was used to estimate least-square means (LSM) for each fixed effect having a significant $F$ value. Duncan's multiple-range test was carried out on raw means calculated for the main effects on embryo development. Development data are referred to frequency percentages of oocytes in IVM, while blastocyst cell counts are absolute values. When blastocyst cell counts in day 7 and day 8 were pooled for analysis, a significant interaction of day $\times$ treatment was detected by means of CATMOD. GLM was used to reject the null hypothesis $\left(\mathrm{H}_{0}: \mathrm{LSM}_{(\mathrm{i})}=\mathrm{LSM}_{(\mathrm{j})}\right)$ for $\mathrm{LSMs}$ within interaction levels. Pregnancy data were submitted to chisquare test of homogeneity for each stratum of treatment day of pregnancy, and results are referred to absolute frequencies.

\section{Results}

\section{Embryo development}

As shown in Table 1, 9-cis-retinoic acid supported morulae, blastocyst and hatching rates comparable to those of embryos derived from oocytes matured in the presence of serum. Ethanol, which was used as a solvent for retinoids, showed a slight stimulatory effect. Serum promoted the appearance of blastocysts on day 6 , earlier than in other groups, but retinoic acid and ethanol enhanced blastocyst developmental kinetics too. Proportions of embryos at the cleavage stage (data not 
Table 1. Effect of the presence of 9-cis-retinoic acid during in vitro maturation of bovine cumulus-oocyte complexes upon subsequent embryonic development

\begin{tabular}{|c|c|c|c|c|c|c|c|c|}
\hline \multirow[b]{2}{*}{ Treatment } & \multirow[b]{2}{*}{$n$} & \multirow[b]{2}{*}{$5-8$ cells } & \multirow[b]{2}{*}{ Morulae } & \multicolumn{5}{|c|}{ Percentage of blastocysts } \\
\hline & & & & Day 6 & Day 7 & Day 8 & Expanded & Hatched \\
\hline 9-cis-Retinoic acid & 202 & $54.0 \pm 4.8^{\mathrm{a}}$ & $53.1 \pm 3.0^{x}$ & $15.3 \pm 2.8^{\mathrm{a}}$ & $40.2 \pm 2.9^{x a}$ & $40.4 \pm 3.4^{\mathrm{ab}}$ & $20.7 \pm 3.6$ & $17.2 \pm 1.3^{x}$ \\
\hline Ethanol & 210 & $59.4 \pm 3.6$ & $41.0 \pm 2.3^{y}$ & $13.6 \pm 2.1^{\mathrm{a}}$ & $29.8 \pm 2.2^{b}$ & $32.1 \pm 2.5^{b c}$ & $18.9 \pm 3.6$ & $10.3 \pm 1.3^{\mathrm{a}}$ \\
\hline Control & 172 & $49.8 \pm 4.9^{\mathrm{a}}$ & $41.7 \pm 3.0^{y}$ & $8.5 \pm 2.8^{b x}$ & $21.6 \pm 2.9^{y}$ & $24.0 \pm 6.6^{\mathrm{cx}}$ & $11.6 \pm 3.5^{b}$ & $3.1 \pm 1.2^{\text {by }}$ \\
\hline Fetal calf serum & 162 & $65.7 \pm 4.9^{b}$ & $57.9 \pm 3.1^{x}$ & $24.6 \pm 2.8^{\mathrm{cy}}$ & $42.6 \pm 3.0^{\mathrm{xa}}$ & $43.8 \pm 3.5^{\text {ay }}$ & $27.8 \pm 4.6^{\mathrm{a}}$ & $19.9 \pm 1.7^{x}$ \\
\hline
\end{tabular}

Data are percentages of matured oocytes, expressed as least-square means $\pm \mathrm{SE}$ (six replicates).

ANOVA and Duncan's test. Values with different superscripts are significantly different: ${ }^{\mathrm{a}, \mathrm{b}, \mathrm{c}}(P<0.05)$; ${ }^{\mathrm{x}, \mathrm{y}, \mathrm{z}}(P<0.01)$.

Table 2. Number of cells after in vitro production of day 7 and day 8 expanded blastocysts derived from cumulus-oocyte complexes matured in medium containing 9-cis-retinoic acid, ethanol, no additives (control) and fetal calf serum

\begin{tabular}{|c|c|c|c|c|c|c|}
\hline \multicolumn{7}{|l|}{ Treatment } \\
\hline \multirow{2}{*}{$\begin{array}{l}\text { In vitro } \\
\text { maturation }\end{array}$} & \multirow[b]{2}{*}{ Day } & \multirow[b]{2}{*}{$n$} & \multicolumn{3}{|c|}{ Number of cells } & \multirow{2}{*}{$\begin{array}{l}\text { Percentage } \\
\text { (ICM:total) }\end{array}$} \\
\hline & & & $\mathrm{ICM}$ & TE & Total & \\
\hline 9-cis-Retinoic acid & 7 & 13 & $36.0 \pm 5.7^{\alpha x}$ & $69.7 \pm 5.6^{\alpha x y}$ & $105.7 \pm 8.2$ & $33.7 \pm 3.8^{\alpha x}$ \\
\hline Ethanol & 7 & 17 & $50.3 \pm 4.9^{y a}$ & $69.0 \pm 4.9^{\alpha x y}$ & $119.4 \pm 7.1^{\mathrm{xa}}$ & $40.7 \pm 3.3^{\alpha \times a}$ \\
\hline Control & 7 & 16 & $44.6 \pm 4.9^{x b}$ & $73.2 \pm 4.9^{\alpha y}$ & $117.9 \pm 7.1^{\mathrm{xa}}$ & $36.3 \pm 3.3^{\alpha x}$ \\
\hline Fetal calf serum & 7 & 13 & $49.2 \pm 5.5^{\mathrm{ab}}$ & $66.7 \pm 5.4^{x y}$ & $115.9 \pm 7.9^{\mathrm{ab}}$ & $43.2 \pm 3.6^{\mathrm{xa}}$ \\
\hline 9-cis-Retinoic acid & 8 & 20 & $39.2 \pm 4.3^{\alpha x}$ & $55.9 \pm 4.3^{x z a}$ & $95.1 \pm 6.2^{\mathrm{c}}$ & $41.9 \pm 2.9^{\alpha x a}$ \\
\hline Ethanol & 8 & 12 & $66.2 \pm 5.7^{\beta у с}$ & $41.5 \pm 5.6^{\beta z b}$ & $107.7 \pm 8.2$ & $59.7 \pm 3.8^{\beta y}$ \\
\hline Control & 8 & 20 & $30.7 \pm 4.4^{\alpha \times d}$ & $62.8 \pm 4.3^{x y}$ & $92.3 \pm 6.0^{y c}$ & $31.5 \pm 2.9^{\alpha \times b}$ \\
\hline Fetal calf serum & 8 & 9 & $49.6 \pm 6.6^{\mathrm{ab}}$ & $69.3 \pm 6.5^{x y}$ & $119.0 \pm 9.4^{\mathrm{a}}$ & $41.1 \pm 3.3^{x}$ \\
\hline
\end{tabular}

Data are least-square means \pm SE. Blastocysts counted were from four (fetal calf serum day 8 ) to nine (control day 8$)$ replicates per group. Values with different superscripts are significantly different within a variable: ${ }^{\mathrm{a}, \mathrm{b}, \mathrm{c}, \mathrm{d}}(P<0.05){ }^{\mathrm{x}, y, \mathrm{z}}(P<0.01) ;{ }^{\alpha, \beta}(P<0.001)$.

ICM: inner cell mass; TE: trophectoderm.

shown in tables) did not differ among groups (values were between $80.5 \pm 3.5$, for negative control, and $85.9 \pm 3.5$, for serum). Ethanol did not promote activation of oocytes (one replicate; five oocytes out of 45 cleaved in the unfertilized ethanol group, and six out of 45 cleaved in the unfertilized untreated controls; no oocyte developed beyond the 5 - to 8 -cell stage).

\section{Differential cell counts}

A total of 120 blastocysts were counted out of 168 samples processed for differential staining. Addition of ethanol during IVM increased values in ICM from day 7 and day 8 blastocysts (Table 2). Besides the ICM increases, addition of ethanol led to day 8 blastocysts showing a marked reduction in trophectoderm, leading to embryos with the highest ICM proportions. Increases in ICM proportions were noted as well with day 8 blastocysts derived from oocytes matured with 9-cis-retinoic acid and FCS. In contrast to day 8 embryos, differences between treatments were not outstanding in day 7 embryos. The total number of cells tended to decrease in day 8 embryos from all groups except the FCS treated group.
Table 3. Pregnancy rates from fresh (one) or vitrified (two) bovine blastocysts transferred to recipients

\begin{tabular}{lcccc}
\hline & \multirow{2}{*}{$\begin{array}{c}\text { Recipients } \\
\text { (embryos }\end{array}$} & \multicolumn{2}{c}{ Recipients diagnosed as pregnant } \\
\cline { 3 - 5 } (oocyte/blastocyst) & transferred) & Day 21 & Day 35 & Day 60 \\
\hline 9-cis-Retinoic acid & $9(12)$ & 5 & 5 & $4^{\mathrm{a}}$ \\
$\quad$ Fresh & $6(6)$ & 4 & 4 & 3 \\
$\quad$ Frozen & $3(6)$ & 1 & 1 & 1 \\
Untreated & $6(9)$ & 4 & 1 & $0^{\mathrm{b}}$ \\
$\quad$ Fresh & $3(3)$ & 3 & 0 & 0 \\
Frozen & $3(6)$ & 1 & 1 & 0 \\
\hline
\end{tabular}

Embryos were derived from oocytes matured in medium containing 9-cis-retinoic acid or no additives (untreated).

Values with different superscripts are significantly different: $\mathrm{a}, \mathrm{b}(P=0.056)$.

\section{Embryo transfer}

Embryos matured in medium containing 9-cis-retinoic acid, both fresh and vitrified or warmed, were viable after transfer to recipients (Table 3), and were capable of establishing pregnancies. This result is in contrast to 
embryos matured without retinoids, with no pregnancies detected at day 60 .

\section{Discussion}

The supply of retinoids to the embryo must be ensured within a physiological range, which makes the choice of dosage for retinoids important, as both excess and deficiency of retinoids cause abundant teratogenic defects due to pleiotrophic activity (for review, see Morriss-Kay and Ward, 1999). A marked response in development and trophectodermal differentiation was obtained by overexposure of bovine oocytes to retinoids (Duque et al., 2002). Retinoic acid at a concentration of 5 nmol $\mathrm{I}^{-1}$ affected embryonic development within the experiments reported here. Comparable results have been obtained with $5 \mathrm{nmol} 9$-cis-retinoic acid $\mathrm{I}^{-1}$ when meiosis is inhibited by roscovitine (Duque et al., 2002), and by Ikeda and co-workers using $1 \mu \mathrm{mol}$ all-transretinoic acid $\mathrm{I}^{-1}$ (personal communication). The 9-cisretinoic acid isomer used in our experiments has been reported to be 25 -fold more potent than the all-trans form (Thaller et al., 1993).

Ethanol can decrease retinoic acid synthesis in competition with all-trans-retinol to inhibit alcohol dehydrogenase (E.C. 1.1.1.1; ADH) (Duester, 1991; Duester et al., 1991; Leo and Lieber, 1999; Molotkov and Duester, 2002). Therefore, ethanol was chosen as a solvent in the present study to outline the effects of exogenous retinoic acid, downstream of the inhibitory point, and to dissociate them from endogenous metabolism of retinoids. Chronic ethanol treatment increases retinoic acid degradation by ethanol-inducible CYP2E1, a P450 which metabolizes retinoic acid to more polar metabolites in vitro (Liu et al., 2001). This process can take days or weeks of treatment to occur, a situation which does not correspond to our experimental conditions. The same above reported effect was seen in acute ethanol treatment in vivo in mice, although the effect of ethanol on retinoic acid synthesis was fourfold greater than on retinoic acid degradation (Molotkov and Duester, 2002).

The presence of 9-cis-retinoic acid, and to a lesser extent ethanol, during IVM improved blastocyst formation and hatching. The developmentally stimulating effects of retinoic acid are consistent with an increased proportion of blastocysts recovered from donors treated with retinol as reported by other authors (Shaw et al., 1995; Whaley et al., 1997, 2000; Eberhardt et al., 1999). Both retinoic acid and all-trans-retinol could act via cumulus-granulosa cells, directly on the oocyte or in both ways, in an autocrine or paracrine manner. Retinoid receptors (Mohan et al., 2001, 2002), RBP (Mohan et al., 2001) and RALDH2 have been detected in immature oocytes. In contrast to the results of the present study, with PVA as a macromolecular source, Avery and Greve (2000) found that 1\% ethanol decreases development of bovine COCs matured with BSA and epidermal growth factor. Ethanol is used to induce oocyte activation at concentrations of about $7 \%$ and short periods (Fukui et al., 1992; Pressice and Yang, 1994a,b). However, $1 \%$ and $2 \%$ ethanol have been shown not to affect nuclear maturation and pronucleus formation after incubation for 1 day (Avery and Greve, 2000). These results are consistent with the findings in the present study, since ethanol did not promote oocyte activation. Although serum promoted the earlier appearance of blastocysts (day 6), blastocyst yields on days 7 and 8 were comparable between FCS and 9-cis-retinoic acid. The role of serum during maturation as a stimulatory agent for blastocyst development is contradictory, being described as either beneficial (Ectors et al., 1992; Carolan et al., 1998; Cho et al., 2001) or unnecessary (Takagi et al., 1991; Chung and Seidel, 1994). Rzucidlo et al. (2001) showed that the presence of serum during the maturation interval affects gene expression pattern in matured bovine oocytes. In a recent study, premature blastulation did not occur when serum was present during IVM and IVF. Instead, a stimulatory effect was noted in cycles before the morula stage with serum during IVM and IVF (Holm et al., 2002).

Maturation with ethanol altered the differentiation process in the bovine blastocyst, with a higher proportion of cells allocated to the ICM pool. Ethanol and 9-cisretinoic acid did not modify total cell numbers in day 7 and day 8 blastocysts, and their influence was strictly reduced to the trophectoderm and ICM distribution. Remarkably, the differences observed are attributable to day 8 blastocysts rather than to day 7 blastocysts, which suggests that these treatments affect maternal regulation of the trophectoderm differentiation process and are dependent on the intrinsic quality of the oocyte. This can be inferred assuming that blastocysts that develop faster derive from more competent oocytes and are more viable after transfer (Hasler et al., 1995) and after cryopreservation (Dinnyes et al., 1999), than blastocysts developing more slowly. Oocytes becoming late expanding day 8 blastocysts would be more sensitive to the treatments used in the present study. Once the retinoid pathway is affected in the COC (i.e. treatments with 9-cis-retinoic acid and ethanol), the ICM:total cell rate increases in day 8 with regard to day 7 blastocysts. In the case of ethanol, the increase was marked and accompanied by an increase in the number of cells in ICM. This is contrary to oocytes matured without additives and with FCS, in which their ICM:total cells did not vary between day 7 and day 8 blastocysts. Generally, the total number of cells in embryos at blastulation decreases in a time-dependent manner in embryos produced in vitro (Yoshioka et al., 1997; Van Soom et al., 1997; de la Fuente and King, 1997; Mori et al., 2002), such as occurs in ICM (Van Soom et al., 1997; de la Fuente and King, 1997). In vivo, embryos exhibit a comparable reduction in both parameters, but 
ICM:total cells remain similar between day 8 and day 9 embryos (de la Fuente and King, 1997).

The above cited developmental promoting side-effects of ethanol would mask its inhibitory effect on retinoic acid synthesis in the COC. However, side-effects would not affect cell distribution in the blastocyst. Some of the observed effects of the retinoid metabolite on trophectoderm and ICM values are in fact an attenuation of the effects exerted by its ethanol solvent. In addition, having observed the magnitude of the effects of ethanol on the number of cells in ICM compared with that of untreated oocytes, there is evidence that endogenous retinoids exert a role in oocyte maturation. Thus, and although not generally opposed to each other, the effect of ethanol leads to a preponderance of ICM, whereas 9-cis-retinoic acid gives rise to more cells in the trophectoderm in day 8 blastocysts.

Ethanol exhibited different behaviour including its stimulating effect on embryo development and its influence on blastocyst differentiation. To our knowledge, the content of endogenous retinoids in the bovine oocyte or granulosa cells are unknown, but $1 \%\left(175 \mathrm{mmol} \mathrm{I}^{-1}\right)$ ethanol should inhibit the ADH activity considerably. In

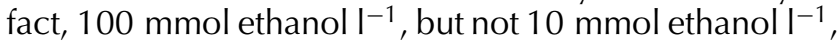
led to a significant decrease in retinoic acid detection in cultured mouse embryos at day 7.5 of age (Deltour et al., 1996), and $17.5 \mathrm{mmol}$ ethanol $\mathrm{I}^{-1}$ enhanced the expression of the proto-oncogene c-Myc (Leach et al., 1999). This promoter of cell proliferation is required for mouse blastocyst development and has been detected in elongating bovine blastocysts (Tetens et al., 2000). In contrast, retinoic acid represses c-Myc expression in a variety of cell types (Sejersen et al., 1986; Falasca et al., 1998; Tinel et al., 1999; Dimberg et al., 2002; Sarkar and Sharma, 2002). The embryo developmental pattern brought about by retinoic acid in the present study reproduces in part the effects reported by Ikeda et al. (2000a,b) using recombinant peptide midkine, a product from a retinoic acid-inducible gene. Other retinoic acid-responsive genes in the bovine embryo are known to be associated with blastocyst formation (leukaemia inhibitory factor, LIF and its receptor LIFr; laminin B1; cytokeratin). Therefore, inhibition of retinoic acid synthesis during IVM would not be used by ethanol to influence development, but alternative mechanisms such as enhancement in the production of cAMP from ATP via stimulation of adenylate cyclase activity (Rabbani et al., 1999). Altered cellular content of cAMP could account for some of the major effects of ethanol (for review, see Klemm, 1998), whereas the addition of retinoic acid was shown not to affect the cAMP content of a granulosa cell culture system (Minegishi et al., 1996, 2000). Maintenance of an optimal intracellular concentration of cAMP before and during IVM ensures a high developmental competence of oocytes to the blastocyst stage and does not alter the number of cells in the blastocyst (Luciano et al., 1999).
It is assumed that a minimal number of ICM cells are required to obtain a pregnancy, and excessive allocation of cells to the TE might lead to pregnancy abnormalities (Van Soom et al., 1996; Leese et al., 1998). Transfer of in vitro cultured bovine embryos gives rise to placentas with increased mass and reduced caruncular area (Farin et al., 2001), together with hydroallantois and polyhydroamnios (van Wagtendonk-de Leeuw et al., 2000). The large offspring syndrome, characterized by abnormally large animals showing a number of congenital defects, can be explained in part by placental abnormality (Bertolini and Anderson, 2002). In embryos produced in vitro there is no difference in amounts of methylation among embryos with high (4.5) or low (0.6) ICM:trophectoderm ratio (Kang et al., 2002), a range similar to the number of cells in the present study (data not shown). This indicates that the wide variation in the ICM:trophectoderm ratio is not necessarily a reflection of epigenetic alteration. It may not be desirable to use culture systems containing ethanol to produce embryos with a large number of cells in the ICM, as ethanol may increase the proportion of cells in the ICM by interfering with important metabolic pathways. In this respect, the apparent better quality of embryos cultured in B2 medium (faster cleavage, earlier blastocyst formation) was not reflected in a reliable number of inner cells of blastocysts (Van Soom et al., 1996), and pregnancy rates were not diminished with regard to embryos cultured in TCM199 (Hasler et al., 1995). Pregnancies and calves born are the best indicator of embryonic viability, and the addition of retinoic acid produced embryos that were viable beyond the expected time for completion of organogenesis (day 42; Hubbert, 1974), in contrast to untreated oocytes. In our laboratory, fresh embryos matured in medium containing serum usually experienced $40 \%$ pregnancy rates as diagnosed at day 60, while no success was attained in the present study in chemically defined conditions before incorporation of 9-cis-retinoic acid to IVM medium. Taken together, the results of the present study indicate that the selected concentration of 9-cis-retinoic acid during IVM probably conditions superior oocyte viability. Subsequent fetal and perinatal development will require careful analysis of calves for normality.

Addition of retinoic acid during IVM improved early development of the bovine oocyte and led to pregnancies upon transfer of day 7 blastocysts. Day 8 blastocysts from oocytes treated with retinoic acid showed improved quality as judged by their ICM values. Ethanol stimulates embryo development but leads to a marked increase in the number of cells in the ICM; whether this observation implies that these blastocysts exhibit compromised viability is worth investigating. The use of retinoids during in vitro maturation is compatible with late pregnancy and, within a physiological dose range and precise conditions, could be used to improve developmental competence of the bovine oocyte. 
The authors thank F. Goyache for critical review and statistical support; Projects Eureka 2573 and AGL 2002-01175.

\section{References}

Avery B and Greve T (2000) Effects of ethanol and dimethylsulphoxide on nuclear and cytoplasmic maturation of bovine cumulus-oocyte complexes Molecular Reproduction and Development 55 438-445

Bertolini M and Anderson GB (2002) The placenta as a contributor to production of large calves Theriogenology 57 181-187

Besenfelder UL, Solti J, Seregi M, Müller M and Brem G (1996) Different roles for B-carotene and vitamin $\mathrm{A}$ in the reproduction of rabbits Theriogenology 45 1583-1591

Carolan C, Lonergan P, Monget P, Monniaux D and Mermillod P (1998) Effect of follicle size and quality on the ability of follicular fluid to support cytoplasmic maturation of bovine oocytes Molecular Reproduction and Development 43 477-483

Chambon P (1996) A decade of molecular biology of retinoic acid receptors FASEB Journal 10 940-954

Cho SR, Hur CG, Lee JG, Rho GJ, Lee HJ, Choe SY and Park CS (2001) Serum-free culture system enhances viability following cryopreservation of bovine embryos produced in vitro. Theriogenology 55333 (Abstract)

Chung YG and Seidel GE (1994) Development of bovine embryos after maturation of oocytes in a simple chemically defined medium supplemented with estrous cow serum and/or pyruvate Theriogenology 41179 (Abstract)

De la Fuente R and King WA (1997) Use of a chemically defined system for the direct comparison of inner cell mass and trophectoderm distribution in murine, porcine and bovine embryos Zygote 5 309320

Deltour L, Ang HL and Duester G (1996) Ethanol inhibition of retinoic acid synthesis as a potential mechanism for fetal alcohol syndrome FASEB Journal 10 1050-1057

Dimberg A, Bahram F, Karlberg I, Larsson LG, Nilsson K and Oberg F (2002) Retinoic acid-induced cell cycle arrest of human myeloid cell lines is associated with sequential down-regulation of cMyc and cyclin E and post-transcriptional up-regulation of p27 (Kip1) Blood 99 2199-2206

Dinnyes A, Lonergan P, Fair T, Boland MP and Yang X (1999) Timing of the first cleavage post-insemination affects cryosurvival of in vitro-produced bovine blastocysts Molecular Reproduction and Development $\mathbf{5 3}$ 318-324

Dolle P, Fraulob V, Kastner P and Chambon P (1994) Development expression of murine retinoid $\mathrm{X}$ receptor (RXR) genes Mechanisms of Development 45 91-104

Duester G (1991) A hypothetical mechanism for fetal alcohol syndrome involving ethanol inhibition of retinoic acid synthesis at alcohol dehydrogenase step Alcoholism - Clinical and Experimental Research 15 568-572

Duester G, Shean ML, McBride MS and Stewart MJ (1991) Retinoic acid response element in the human alcohol dehydrogenase gene $\mathrm{ADH} 3$ : implications for regulation of retinoic acid synthesis Molecular and Cellular Biology 11 1638-1646

Duque P, Díez C, Royo L, Lorenzo PL, Carneiro G, Hidalgo CO, Facal N and Gómez E (2002) Enhancement of developmental capacity of meiotically inhibited bovine oocytes by retinoic acid Human Reproduction 17 2706-2714

Eberhardt DM, Will WA and Godkin JD (1999) Retinol administration to superovulated ewes improves in vitro embryonic viability Biology of Reproduction 60 1483-1487

Ectors FJ, Fontes RS, Thonon F, Delval A, Figueiredo JR, Beckers J-F and Ectors $\mathbf{F}$ (1992) Effect of non-protein medium during in vitro maturation on in vitro development of bovine embryos Theriogenology 37206 (Abstract)

Falasca L, Favale A, Gualandi G, Maietta G and Conti Devirgiliis L (1998) Retinoic acid treatment induces apoptosis or expression of a more differentiated phenotype on different fractions of cultured fetal rat hepatocytes Hepatology 28 727-737

Farin PW, Crosier AE and Farin CE (2001) Influence of in vitro systems on embryo survival and fetal development in cattle Theriogenology 55 $151-170$

Fukui Y, Sawai K, Furudate M, Sato N, Iwasumi Y and Ohsaki K (1992) Parthenogenetic development of bovine oocytes treated with ethanol and cytochalasin B after in vitro maturation Molecular Reproduction and Development 33 357-362

Hasler JF, Henderson WB, Hurtgen PJ et al. (1995) Production, freezing and transfer of bovine IVF embryos and subsequent calving results Theriogenology 43 141-152

Hidalgo C, Díez C, Duque P, Facal N, Prendes JM, Fernández I and Gómez E (2002) Improved cumulus-oocyte complex yields from heifers treated with retinol Theriogenology 57672 (Abstract)

Holm P, Booth PJ, Schmidt MH, Greve T and Callesen H (1999) High bovine blastocyst development in a static in vitro production system using SOFaa medium supplemented with sodium citrate and myo-inositol with or without serum-proteins Theriogenology 52 683-700

Holm P, Booth PJ and Callesen H (2002) Kinetics of early in vitro development of bovine in vivo- and in vitro-derived zygotes produced and/or cultured in chemically defined or serum-containing media Reproduction 123 553-565

Hubbert WT (1974) Factors affecting survival of the bovine fetus and neonate Theriogenology 1 15-34

Ikeda S, Nishikimi A, Ichihara-Tanaka K, Muramatsu T and Yamada M (2000a) cDNA cloning of bovine midkine and production of the recombinant protein, which affects in vitro maturation of bovine oocytes Molecular Reproduction and Development 57 99-107

Ikeda S, Ichihara-Tanaka K, Azuma T, Muramatsu T and Yamada M (2000b) Effects of midkine during in vitro maturation of bovine oocytes on subsequent developmental competence Biology of Reproduction 63 1067-1074

Kaidi S, Donnay I, Massip A and Dessy F (2000) Effect of freezing or vitrification on the quality of in vitro-produced bovine blastocysts Theriogenology 53257 (Abstract)

Kang YK, Park JS, Koo DB, Choi YH, Kim SU, Lee KK and Han YM (2002) Limited demethylation leaves mosaic-type methylation states in cloned bovine pre-implantation embryos EMBO Journal 21 1092-1100

Kim JY, Kinoshita M, Ohnishi M and Fukui Y (2001) Lipid and fatty acid analysis of fresh and frozen-thawed immature and in vitro matured bovine oocytes Reproduction 122 131-138

Klemm WR (1998) Biological water and its role in the effects of alcohol Alcohol 15 249-267

Leach RE, Rout UK, Schultz JF, Saunders DE and Armant DR (1999) Ethanol elevates c-Myc levels in cultured mouse preimplantation embryos Alcoholism - Clinical and Experimental Research 23 778-784

Leese HJ, Donnay I and Thompson JG (1998) Human assisted conception: a cautionary tale Lessons from domestic animals Human Reproduction 4 184-202

Leo MA and Lieber ChS (1999) Alcohol, vitamin A, and $\beta$-carotene: adverse interactions, including hepatotoxicity and carcinogenicity American Journal of Clinical Nutrition 69 1071-1085

Liu C, Russell RM, Seitz HK and Wang XD (2001) Ethanol enhances retinoic acid metabolism into polar metabolites in rat liver via induction of cytochrome P4502E1 Gastroenterology 120 179-189

Luciano AM, Pocar P, Milanesi E, Modina S, Rieger D, Lauria A and Gandolfi F (1999) Effect of different levels of intracellular cAMP on the in vitro maturation of cattle oocytes and their subsequent development following in vitro fertilization Molecular Reproduction and Development 54 86-91

McEvoy TG, Coull GD, Broadbent PJ, Hutchinson JS and Speake BK (2000) Fatty acid composition of lipids in immature cattle, pig and sheep oocytes with intact zona pellucida Journal of Reproduction and Fertility 118 163-170

Mangelsdorf DJ, Borgmeyer U, Heyman RA, Zhou JY, Ong ES, Oro AE, Kakizuka A and Evans RM (1992) Characterization of three RXR genes that mediate the action of 9-cis retinoic acid Genes and Development 6 329-344 
Mangelsdorf DJ, Umesono K and Evans RM (1994) The retinoid receptors. In The Retinoids: Biology, Chemistry and Medicine pp 319-349 Eds MB Sporn, AB Roberts and DS Goodman. Raven Press, New York

Minegishi T, Karino S, Tano M, Ibuki Y and Miyamoto K (1996) Regulation of midkine messenger ribonucleic acid levels in cultured rat granulosa cells Biochemical and Biophysical Research Communications 229 799-805

Minegishi T, Hirakawa T, Kishi H, Abe K, Tano M, Abe $\mathrm{Y}$ and Miyamoto $\mathrm{K}$ (2000) The mechanisms of retinoic acid-induced regulation on the follicle-stimulating hormone receptor in rat granulosa cells Biochimica et Biophysica Acta 1495 203-211

Mohan M, Malayer JR, Geisert RD and Morga GL (2001) Expression of retinol-binding protein messenger RNA and retinoic acid receptors in preattachment bovine embryos Molecular Reproduction and Development 60 289-296

Mohan M, Malayer JR, Geisert RD and Morgan GL (2002) Expression patterns of retinoid $X$ receptors, retinaldehyde dehydrogenase, and peroxisome proliferator activated receptor gamma in bovine preattachment embryos Biology of Reproduction 66 692-700

Molotkov A and Duester G (2002) Retinol/ethanol drug interaction during acute alcohol intoxication in mice involves inhibition of retinol metabolism to retinoic acid by alcohol dehydrogenase Journal of Biological Chemistry 27722 553-22 557

Mori M, Otoi T and Suzuki T (2002) Correlation between the cell number and diameter in bovine embryos produced in vitro. Reproduction in Domestic Animals 37 181-184

Morriss-Kay GM and Ward SJ (1999) Retinoids and mammalian development International Review of Cytology 188 73-131

Ong DE and Page DL (1986) Quantitation of cellular retinol-binding protein in human organs American Journal of Clinical Nutrition 44 425-430

Parrish JJ, Susko-Parrish JL, Leibfried-Ruthledge ML, Critser ES, Eyestone WH and First NL (1986) Bovine in vitro fertilization with frozen-thawed semen Theriogenology 25 591-600

Presicce GA and Yang X (1994a) Nuclear dynamics of parthenogenesis of bovine oocytes matured in vitro for 20 and 40 hours and activated with combined ethanol and cycloheximide treatment Molecular Reproduction and Development 37 61-68

Presicce GA and Yang X (1994b) Parthenogenetic development of bovine oocytes matured in vitro for $24 \mathrm{hr}$ and activated by ethanol and cycloheximide Molecular Reproduction and Development 38 380-385

Rabbani M, Nelson EJ, Hoffman PL and Tabakoff B (1999) Role of protein kinase $C$ in ethanol-induced activation of adenyl cyclase Alcoholism Clinical and Experimental Research 23 77-86

Rzucidlo SJ, Gibbons J and Stice SL (2001) Comparison by restriction fragment differential display RT-PCR of gene expression pattern in bovine oocytes matured in the presence or absence of fetal calf serum Molecular Reproduction and Development 59 90-96

Sarkar SA and Sharma RP (2002) Modulation of c-myc, max and mad gene expression during neural differentiation of embryonic stem cells by alltrans-retinoic acid Gene Expression 10 125-135

Sejersen T, Bjorklund H, Sumegi J and Ringertz NR (1986) N-myc and c-src genes are differentially regulated in PCC7 embryonal carcinoma cells undergoing neuronal differentiation Journal of Cellular Physiology 127 274-280
Shaw DW, Farin PW, Washburn SP and Britt JH (1995) Effect of retinol palmitate on ovulation rate and embryo quality in superovulated cattle Theriogenology 44 51-58

Takagi Y, Mori K, Tomizawa M, Takahashi T, Sugawara S and Masaki J (1991) Development of bovine oocytes matured, fertilized and cultured in a serum-free, chemically defined medium Theriogenology 35 1197-1207

Tetens F, Kliem A, Tscheudschilsuren G, Navarrete Santos A and Fischer B (2000) Expression of proto-oncogenes in bovine preimplantation blastocysts Anatomy and Embryology 201 349-355

Thaller C, Hofmann C and Eichele G (1993) 9-cis-Retinoic acid, a potent inducer of digit pattern duplications in the chick wing bud Development 118 957-650

Tinel M, Elkahwaji J, Robin MA, Fardel N, Descatoire V, Haouzi D, Berson A and Pessayre D (1999) Interleukin-2 overexpresses C-Myc and down-regulates cytochrome P-450 in rat hepatocytes Journal of Pharmacology and Experimental Therapeutics 289 649-655

Van Soom A, Boerjan M, Ysebaert MT and De Kruif A (1996) Cell allocation to the inner cell mass and the trophectoderm in bovine embryos cultured in two different media Molecular Reproduction and Development 45 171-182

Van Soom A, Ysebaert MT and De Kruif A (1997) Relationship between timing of development, morula morphology, and cell allocation to inner cell mass and trophectoderm in in vitro-produced bovine embryos Molecular Reproduction and Development 47 47-56

van Wagtendonk-de Leeuw AM, Mullaart E, de Roos APW, Merton JS, den Daas JHG, Kemp B and de Ruigh L (2000) Effects of different reproduction techniques: $\mathrm{AI}, \mathrm{MOET}$, or IVP on health and welfare of bovine offspring Theriogenology 53 575-597

Wardlaw SA, Bucco RA, Zheng WL and Ong DE (1997) Variable expression of cellular retinol- and cellular retinoic acid-binding proteins in the rat uterus and ovary during the estrous cycle Biology of Reproduction $\mathbf{5 6}$ 125-132

Whaley SL, Hedgpeth VS and Britt JH (1997) Evidence that injection of vitamin A before mating may improve embryo survival in gilts fed normal or high energy diets Journal of Animal Science 75 1071-1077

Whaley SL, Hedgpeth VS, Farin CE, Martus NS, Jayes FCL and Britt JH (2000) Influence of vitamin A injection before mating on oocyte development, follicular hormones, and ovulation in gilts fed high-energy diets Journal of Animal Science 78 1598-1607

Yoshioka K, Mazni Othman A, Taniguchi T, Yamanaka H and Sekikawa K (1997) Differential patterns of blastulation in bovine morulae cultured in synthetic oviduct fluid medium containing FCS or BSA Theriogenology 48 997-1006

Zheng WL, Bucco RA, Sierra-Rievera E, Osteen KG, Melner MH and Ong DE (1999) Synthesis of retinoic acid by rat ovarian cells that express cellular retinoic acid-binding protein-II Biology of Reproduction 60 110-114

Zhuang YH, Ylikomi T, Lindfors M, Piippo S and Tuohimaa P (1994) Immunolocalization of retinoic acid receptors in rat, mouse and human ovaries and uterus Journal of Steroid Biochemistry and Molecular Biology 48 61-68

Received 3 September 2002.

First decision 21 October 2002.

Revised manuscript received 4 November 2002.

Accepted 19 November 2002. 